\title{
Faculty Status for Academic Librarians: A Review of the Literature
}

\section{Emily Werrell and Laura Sullivan}

The faculty status issue continues to hold considerable attention among academic librarians. Although it remains a contested subject, there have been changes in general opinion about faculty status over the past few decades. This article is intended to identify the most significant aspects of the topic and to provide a general survey of the literature since 1974. An accompanying annotated bibliography of 121 items will be available through the ERIC Clearinghouse in early 1987.

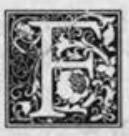

or at least the past forty years, academic librarians have been deeply concerned with their professional status. Currently, the majority of academic librarians possess faculty status, ${ }^{1}$ which is defined as "an official recognition by an institution of higher education that librarians are part of the instructional and research staff by conferment of ranks and titles identical to those of faculty, and commensurate benefits, rights, and responsibilities. ${ }^{\prime 2}$ This review is intended to illustrate representative attitudes and practices concerning the faculty status issue from the mid-1970s to 1985. For the purposes of this article, faculty status differs from "academic status," which implies neither identical titles and ranks nor all of the rights and responsibilities of faculty. In addition, this article does not treat the much broader issue of professional status or professionalism in the library science and information field.

\section{BACKGROUND}

While faculty status is certainly widespread, it is almost as controversial an is- sue now as it was a few decades ago, when concerned constituents of ACRL were beginning to fight for that organization's official endorsement of faculty status. In 1959, ACRL did endorse faculty status as a right, but it was not until 1971 that its Academic Status Committee drafted standards and an official statement (jointly prepared by ACRL, the AAUP, and the Association of American Colleges) on the issue.

The path to this official endorsement was a long one, as is documented by Arthur McAnally in "Status of the University Librarian in the Academic Community. ${ }^{\prime 3}$ McAnally points out that, although librarians had always considered themselves to be educators, it was during the postwar period that their responsibilities changed drastically; rapid growth in collections and programs and new emphasis on the use of library resources in courses of study required better-trained and more specialized librarians. As they began to recognize their increasingly complex role, librarians became dissatisfied with their relatively low status.

Emily Werrell is Reference/Instructional Services Librarian and Laura Sullivan is Reference Librarian at Northern Kentucky University, Highland Heights, Kentucky 41076. 
Many articles written during the 1930s and 1940 s, if they did not support faculty status per se, did urge the adoption of some classification that would lend greater dignity and significance to library work. As the movement gained impetus, the faculty model was generally accepted as the most appropriate one for attaining this improved status. The rationale for this hinged primarily upon librarians' image of themselves as educators, with scholarly interests and knowledge on a par with those of the teaching faculty. By the late 1940 s, surveys and review articles abounded in the library literature measuring and analyzing the degree to which librarians were recognized as members of the academic community. This analysis continues to the present day.

There was convincing reasoning behind this push for faculty status. Most academic librarians could see no better alternative for obtaining the recognition, respect, and privileges they felt they deserved. They wanted to be active members of their campuses-to have a voice in academic affairs, to have the opportunity to contribute in a scholarly fashion to the academic world, and to be recognized as partners of the teaching faculty in the education of students. According to the ACRL standards,

without the librarian, the quality of teaching, research, and public services in our colleges and universities would deteriorate seriously and programs in many disciplines could no longer be performed. His contribution is intellectual in nature and is the product of considerable formal education, including professional training at the graduate level. Therefore, college and university librarians must be recognized as equal partners in the academic enterprise, and they must be extended the rights and privileges which are not only commensurate with their contributions, but are necessary if they are to carry out their responsibilities. ${ }^{4}$

In addition, the argument was made that faculty status would upgrade the profession by attracting higher-quality personnel.

\section{FACULTY STATUS TODAY}

In the 1980 s, most academic librarians (almost 79 percent) have some form of fac- ulty status. ${ }^{5}$ This includes, in most cases, all of the responsibilities (i.e., research and publication, community service, activity in campus and professional affairs) and some of the privileges (i.e., opportunity for tenure, support for continued education, involvement in university governance) of teaching faculty. There are still some glaring deficiencies in the privileges academic librarians enjoy. For example, most academic librarians work under twelve-month contracts, do not receive salaries equal to those of teaching faculty with the same rank, do not enjoy a flexible work day and week, and are not provided with the compensatory release time necessary for them to contribute in a scholarly manner to their field. Add to these tangible disadvantages the collegial and social setbacks resulting from a negative image and an ambiguous role, and it is clear that academic librarians have far to go.

Still, many of us feel, as McAnally did in 1971, that "librarians must either join the faculty or be permanently relegated to peripheral and inferior roles." ${ }^{\prime 6}$ While it is true that academic librarians desire the working conditions and influence necessary to provide the best possible service and to make the highest possible contributions, there have been recent rumblings from within the ranks whether faculty status is the most appropriate vehicle for attaining these conditions.

In 1981, Richard Meyer reported that faculty status was held in disfavor by five times as many academic librarians as five years earlier. Many felt "relegated to second-class status. They felt pressure because of the necessity to compete with faculty-publish or perish-without the time to do it." 7 For many years, academic librarians with faculty status have been trying to juggle all of their administrative, supervisory, public service, technical support, and even clerical responsibilities as librarians with the increasingly stringent scholarly, collegial, and community responsibilities they have as faculty members-all the while continuing to work forty hours a week, eleven months a year, and to earn salaries consistently at the low end of the pay scale for similarly ranked faculty at their institutions. The 
strain is beginning to show.

Other arguments against faculty status maintain that the problem lies not in working conditions, but in the fact that our profession lacks a sound identity of its own. Recent articles argue that we as librarians should be respected on the strength of our unique contributions to the academic world, and not according to criteria set for a profession that differs from our own. Lance Query said it this way: "Until academic librarians are recognized for what they really do rather than for a dimly defined and selectively relevant 'teaching' function, their role in the mission of the college or university will continue to be misunderstood and, inevitably, undervalued. ${ }^{\prime 8}$ There is a growing sentiment that we may have been mistaken when we adopted faculty status so wholeheartedly in order to elevate our own positions.

Several authors decry the decision of ACRL-and academic librarians in general-to ride the coattails of teaching faculty. In a 1983 article, John DePew states that "the ranks and titles of the teaching faculty should not be used because they are the labels of another profession ... when librarians use them for their own, they undermine the integrity of their own profession, and in a real sense deny it, by trying to use what Robert Pierson calls the 'protective coloration' of another profession to label it what it isn't. ${ }^{\prime \prime 9}$ Meyer states that "the implementation of faculty status is tantamount to leaving the profession for one of a supposedly higher status. ${ }^{10}$ In a 1984 survey, Thomas English found that most academic administrators believe that granting faculty status to librarians does nothing to benefit the university and that faculty appointments are unsuitable for librarians. ${ }^{11}$

As the belief that the faculty status model is inappropriate has gained popularity, some librarians have made an effort to change their status from a faculty model to something unique, reflecting their special contributions. As DePew wrote, "some libraries that did make an effort to implement full faculty status in accordance with the ACRL standards have begun to have second thoughts. ${ }^{\prime 12}$ In 1983,
Anthony Tassin reported that "large numbers of academic librarians are beginning to doubt its benefits or even assert their conviction that faculty status is not to their advantage." ${ }^{\prime 3}$ English's 1983 survey of ARL libraries found that "the oncepopular thrust to shift academic librarians from nonfaculty to faculty status - a movement of considerable impetus in the 1960 s and early 1970 s-had apparently run its course. ${ }^{\prime 14}$ Indeed, English found that the only shifts of this kind in recent years were in the other direction. W. Bede Mitchell and L. Stanislava Swieszkowski report that of the thirty-seven respondents to their questionnaire on status and publications, sixteen institutions in the last ten years have changed their librarians' status to nontenure track and twelve have adopted a tenure-track system not requiring publication. ${ }^{15}$ Despite the fact that some creative alternatives have been implemented, a resolution of the problem on a national scale remains elusive.

\section{SPECIFIC ISSUES}

In addition to articles about faculty status trends, the literature is saturated with research exploring, defining, and questioning the spokes of the faculty status wheel: publication/scholarship, governance and collegiality, librarians as teachers, collective bargaining, salary, contract year, peer review, and other related issues. The following selected viewpoints represent the more vocal issues in the literature.

\section{Publication/Scholarship}

This salient topic poses a dilemma for many librarians-are we librarians only, scholars or authors, or some fuzzy combination of all three? As the emphasis on scholarship continues to grow, a further complication exists within this added requirement. Frederick Isaac, concerned that pressure exists "on all librarians to contribute to the profession through the development, achievement, and publication of significant research," discusses several resultant dilemmas facing the librarian. For example, if one accepts the premise that publication by librarians is valuable-and not all do-the next ques- 
tion is, Should librarians publish only in librarianship, or in an outside discipline as well? ${ }^{16}$

While some argue that librarians must produce more (and increasingly improved) research concerning their field, John Kaiser presents another angle. He insists that for the librarian and library science student to attain "bona fide academic status," he or she must gain competence in a subject field and publish in that subject field. This will yield closer faculty contact and a chance for the librarian to be accepted as a member of the academic community. ${ }^{17}$

A problem also exists for those librarians who have little interest in publishing or who feel that service is more important than scholarship. ${ }^{18}$ Willis Bridegam asserts that "a requirement or an expectation to perform research and to publish it could result in a serious reduction in the level of service provided to the library's users. ${ }^{19}$ John Campbell, sarcastically addressing library school faculty, says "give up your quest to teach people to catalog, to do reference, to serve a public. Teach them instead to write, research, get things published. ${ }^{\prime 20}$ On the other hand, from a survey by Dwight Burlingame and Joan Repp, several academic librarians who published felt that research enhances the quality of library service rather than detracting from it. ${ }^{21}$

According to some authors, factors such as lack of release time and contract year (twelve months for most librarians) prevent librarians from devoting the amount of time it takes to conduct serious research. In a survey by Jack Pontius and other U.S. academic members of ARL libraries, 94 percent of those libraries with faculty status required research for promotion and tenure, however only 9 percent provided regular release time for such research. ${ }^{22}$ In a survey by Ronald Rayman and Frank Goudy of the ninetyfour ARL libraries, thirty-five libraries provided release time while thirty-three did not. ${ }^{23}$

With increasing pressure on librarians to publish, the lack of release time places the burden on librarians to initiate research, according to Daniel Traister. ${ }^{24}$ However, Burlingame and Repp surveyed academic librarians (authors and nonauthors) concerning what motivated them to publish and found that institutional encouragement (i.e. release time), "excluding the promise of tenure or promotion, is not a factor in successful publication efforts. ${ }^{\prime 25}$

Whether or not release time is a factor, Mitchell and Swieszkowski found that research and publication affect tenure. Their survey of 138 Center for Research Libraries members showed that lack of sufficient research and publication are the most frequent causes of librarians being denied tenure. ${ }^{26}$

Several articles in the literature have dealt with means to aid librarians faced with the research requirement. Susan Miller and others explained the Academic Library Research Committee at the Ohio State University Libraries, which was charged "to promote research activities and projects by the Libraries faculty, to identify areas and/or interests to be investigated, to coordinate research activities within the faculty, to solicit funds and individuals to do research, and to publicize research activities. ${ }^{127}$ This committee also designed a reassigned time policy for the OSU libraries. Darrell Jenkins, Kathy Cook, and Mary Anne Fox detailed the design of the Research Interest Group at Southern Illinois University at Carbondale. This provides those interested a chance to hear outside speakers and faculty members discuss research experiences and offer advice. ${ }^{28}$

\section{Governance and Collegiality}

Governance and collegiality concerns are also evident in the literature. Page Ackerman reviewed the governance issue, specifically addressing ACRL Standards for Faculty Status for College and University Librarians (1975) and the Statement on Faculty Status of College and University Librarians (1975). Noting deficiencies in these documents, Ackerman says the Statement "fails to specify the means by which librarians shall achieve voice in institutional governance."' The Standards are also ambiguous: "They specify membership in the senate as the means for achieving voice and place no role and authority of the library faculty in internal govern- 
ance." The lack of a precise role for librarians in institutional governance is due in part to confusion among academic colleagues about the status of librarians, as well as to ambiguity in the profession's own standards. ${ }^{29}$

In the area of library governance, there are distinct differences between the traditional hierarchical structure of libraries and the traditional collegial structure of academic departments. Adeline Tallau and Benjamin Beede say "the rarity of a collegial form of library governance is a reflection of the restricted dimensions of the 'faculty status' accorded to librarians in most colleges and universities." ${ }^{30}$ Another explanation for these differences is the difficulty in applying a collegial structure to a bureaucratic setting. Robert Sewell says "it is still widely felt in the profession that in administrative structure, libraries resemble hospitals more than universities ... [ [in that] they are composed of large work forces ranging broadly in status, ${ }^{\prime \prime 31}$ whereas in colleges and universities, the faculty members are equals.

Tallau and Beede argue that librarians should mimic the collegiality of teaching departments in order to attain true faculty status. ${ }^{32}$ At Dickinson College, the library faculty succeeded in changing from a hierarchical form of governance to a collegial one. Some changes included a ninemonth contract rather than an elevenmonth one, and one month in the summer devoted to research and professional development. The library became the "Department of Library Resources, with a chairperson elected by department members and approved by the dean, as all other department chairpersons were ... . this meant rotation of the chairpersonship as well as department heads!"'33

Other less revolutionary means of improving governance and collegiality have been reported. The library at Georgia State University chose to make their governance more specific and participative. Michael McDavid details the process of establishing bylaws at Georgia State and the resulting faculty committees and an administrative council. ${ }^{34}$

Richard Meyer admits that an alignment with the faculty model has supposedly been helpful in raising librarians' status and improving self-image. Nevertheless, he labels collegiality and the faculty model inappropriate due to an evaluation procedure ill-fitted to librarians, and the expectation for librarians to do research that is wrong "if pursuit of scholarly studiesjust for the sake of evaluation criteria-or of teaching diverts the academic librarian from providing service. ${ }^{\prime \prime 35}$ Instead, Meyer desires a professional librarian model and calls for librarians to be committed to service and "to pursue self-esteem and status on the basis of good service rather than on artificial attachments. ${ }^{136}$ Louise Sherby opts for librarians to pursue extraprofessional activities, such as committee work and institutional service, enabling the teaching faculty to acknowledge librarians as equals.

\section{Librarians as Teachers}

Librarian identification with faculty, especially in the role of teacher, is also significant in the faculty status question. Pauline Wilson's well-known article on librarians as teachers describes this concept as an organization fiction, "disguising the truth, and it has contributed to the difficulty librarians have had in explaining their work and developing an understandable and believable professional identity. ${ }^{38}$ Wilson claims that library instruction may be a function of academic librarians, but this in itself is not sufficient to warrant librarians' right to faculty status.

David Peele is of the opinion that teaching is only a very small part of what librarians do, and that it cannot be compared to the teaching of subject matter in the classroom. While granting that librarians do have some knowledge of subject areas, he feels "that in the majority of cases knowledge of content does not necessarily mean we are teaching it, and I also believe that there is a difference between what we do at our desks and what they do at their lecterns. There certainly is such a difference from the point of view of the student." ${ }^{139}$ He also wonders how technical services librarians fit into the teaching role.

John Budd has an opposite viewpointlike teachers, librarians provide students with information "in a systematic and or- 
derly fashion, thus increasing the student's store of knowledge. ${ }^{\prime 40}$ The only difference is that a student's informational need is met at the reference desk and not in the classroom. The librarian's role as teacher, as well as researcher and publisher, is important in attaining faculty status and does not strip librarians of their identity as librarians. ${ }^{41}$

Although Mary Biggs identifies faculty status as one area of tension between faculty and librarians, ${ }^{42}$ the two groups are apparently compatible according to Mary Huston and Frank Motley. Evergreen State College has devised a librarianfaculty rotation whereby librarians may work as teachers for a term with all the benefits (faculty pay scale, nine-month contract); likewise, teachers take on the duties of public service librarians, such as handling collection development, bibliographic instruction, and reference. ${ }^{43}$

Becoming accepted as teachers may continue to be an uphill struggle for librarians, as surveys of academic administrators and teaching faculty have shown that academic librarians are not generally perceived to be teachers. ${ }^{44}$ Opinions differ regarding whether this is due to librarians' failing to make known what teaching functions they perform, to the fact that librarians in general are simply not as well educated as faculty, or to sheer ignorance and ill will on the part of teaching faculty. ${ }^{45}$ Perhaps the most fundamental cause is proposed by Wilson: "There is no basis for recognition. It is not that teachers and professors will not recognize librarians as teachers. Rather, it is that they cannot. There is nothing visible with which a connection can be made to permit or produce recognition." 46

\section{Collective Bargaining}

Another component of faculty status is what Margaret Beckman said "will be the normal pattern for the majority of academic library staffs within the next decade" -collective bargaining. ${ }^{47}$ Presently, there is little in the literature to substantiate this prediction; apparently, the interest in collective bargaining was highest in the mid- to late seventies as indicated by the flurry of publications on the subject surfacing at the time.$^{48}$ However, a recent study indicates an increase in union activity on campuses in the last few years. One such campus is Curry College, whose bargaining agent is the AAUP. The librarians hold faculty ranks, are eligible for sabbaticals and research support, have long vacations and twenty-eight-hour work weeks in the summer, and enjoy generous benefits including maternity, paternity, and adoption leave. The study also reports that recent union negotiations have dealt with working conditions and personnel evaluation; grievance issues have included leave policy, sexual harassment, and flexible scheduling. ${ }^{49}$

John Weatherford believes collective bargaining is a positive factor in the quest for full-fledged faculty status. He examines the ACRL Statement on Rights and Privileges, which "recommends nine rights or privileges that academic librarians ought to share equally with all faculty members, and provides for sanctions against colleges and universities that do not grant them." 50 These rights are selfdetermination on the job, library governance, college and university governance, compensation, tenure, promotion, leaves, research funds and academic freedom. Weatherford states that since the inception of faculty collective bargaining in four-year colleges and universities, parity for academic librarians has not yet been achieved in all nine areas of the ACRL Statement, although some progress has been made.

Belle Zeller also recommends that librarians "make themselves an integral part of their faculty unions," although at the same time recognizing the obstacles to faculty unionization, such as faculty reluctance and the lack of authorization by state legislatures for public employees to bargain collectively. ${ }^{51}$ An additional obstacle is the minority status of librarians on a unionized campus. The library faculty needs to be assertive, cohesive, and wellorganized so that their interests will not be "compromised at the bargaining table by the larger group." D2. David Kreh, documenting the history of faculty status and collective bargaining at SUNY, calls for librarians to participate in their unions at 
the state and local levels so that their special concerns will be recognized. ${ }^{53}$

A survey of librarians at six universities by Stella Bentley showed some interesting results. For example, a bargaining agent had an effect on length of contract yearan academic-year contract was more likely if librarians were included in the bargaining unit. However, the study showed that librarians with a bargaining agent were less satisfied with their economic status. The presence of a bargaining agent did not significantly affect their research, publication, and professional activities. ${ }^{54}$ Further research is necessary to see if the statistics have changed since this study.

Finally, collective bargaining raises the issue of the power possessed by librarians on campus. In 1975, Weatherford called collective bargaining "an exercise in power. ${ }^{\prime 55}$ David Sparks states, "The advent of collective bargaining is simply the ultimate test, for librarians, of their cohesiveness as a professional group, their commitment to the profession, their understanding of the power relationships within the academic situation where they work, and their ability to convince the principals in this struggle of the validity of their claims." ${ }^{156}$

While peer review, salaries, contract year, and other benefits (i.e. sabbaticals) are covered in the literature, the number of publications is small in comparison to some of the previously mentioned issues. This does not imply the unimportance of these issues, or the lack of significant research findings. Still, the specific areas of concern covered in this article represent the ones most widely discussed in the recent literature. Because the topic continues to generate heated debate as well as scientific appraisal, it is hoped that this essay provides a thought-provoking overview of the trends in attitudes and practices related to faculty status and the many peripheral areas of concern surrounding the issue.

\section{REFERENCES}

-1. John N. Depew, "The ACRL Standards for Faculty Status: Panacea or Placebo," College and Research Libraries 44:407 (Nov. 1983).

2. Heartsill Young, ed., The ALA Glossary of Library and Information Science (Chicago: American Library Assn., 1983), p.90.

3. Arthur M. McAnally, "Status of the University Librarian in the Academic Community," in Faculty Status for Academic Librarians: A History and Policy Statements, comp. ACRL Committee on Academic Status (Chicago: American Library Assn., 1975), p.1-30.

4. "Standards for Faculty Status for College and University Librarians," in Faculty Status for Academic Librarians, p.32.

5. DePew, "ARCL Standards," p.407.

6. McAnally, "Status of the University Librarian," p.5.

- 7. Richard W. Meyer, "Faculty Status and Academic Librarians: Are There Second Thoughts?" North Carolina Libraries 39:43 (Winter 1981).

8. Lance Query, "Librarians and Teaching Faculty: Disparity within the System," Academe 71:16 (July-Aug. 1985).

9. DePew, "ACRL Standards," p.411.

10. Meyer, "Faculty Status and Academic Librarians," p.42.

- 11. Thomas G. English, "Administrators' Views of Library Personnel Status," College and Research Libraries 45:191-92 (May 1984).

12. DePew, "ACRL Standards," p.409.

13. Anthony G. Tassin, "Faculty Status for Librarians: Progress and Perplex," LLA Bulletin (Louisiana Library Association) 47:83 (Fall 1984).

14. Thomas G. English, "Librarian Status in the Eighty-Nine U.S. Institutions of the Association of Research Libraries: 1982," College and Research Libraries 44:199 (May 1983).

15. W. Bede Mitchell and L. Stanislava Swieszkowski, "Publication Requirements and Tenure Approval Rates: An Issue for Academic Librarians," College and Research Libraries 46:254 (May 1985).

16. Frederick Isaac, "Librarian, Scholar or Author? The Librarian's New Dilemma," Journal of Academic Librarianship 9:216-20 (Sept. 1983).

17. John R. Kaiser, "The Librarian as Scholar," in Options for the Eighties: Proceedings of the Second Na- 
tional Conference of the Association of College and Research Libraries, eds. Michael D. Kathman and Virgil F. Massman (Greenwich, Conn.: JAI Press, 1982), p.433-37.

18. Isaac, "Librarian, Scholar or Author?," p.218.

19. Willis Bridegam's article, "A Research Requirement for Librarians?" appears as part of a symposium: Beverly J. Toy, "The Role of the Academic Librarian: A Symposium," Joumal of Academic Librarianship 4:135-36 (July 1978).

20. John Campbell, "Publish or Perish, Library-Style," Wilson Library Bulletin 52:250 (Nov. 1977).

21. Dwight F. Burlingame and Joan Repp, "Factors Associated with Academic Librarians' Publishing in the 70s: Prologue for the Eighties," in Options for the Eighties: Proceedings of the Second National Conference of the Association of College and Research Libraries, eds. Michael D. Kathman and Virgil F. Massman (Greenwich, Conn.: JAI Press, 1982), p.403.

22. Jack F. Pontius and others, Faculty Status, Research Requirements, and Released Time (ERIC Document Reproduction Service, ED 183 147, 1978), p.7.

23. Ronald Rayman and Frank Wm. Goudy, "Research and Publication Requirements in University Libraries," College and Research Libraries 41:45 (Jan. 1980).

24. Daniel Traister, "How Much Research Would a Research Librarian Do if a Research Librarian Could Do Research?" in Options for the Eighties: Proceedings of the Second National Conference of the Association of College and Research Libraries, eds. Michael D. Kathman and Virgil F. Massman (Greenwich, Conn.: JAI Press, 1982), p.465.

25. Burlingame and Repp, "Factors Associated with Academic Librarians' Publishing in the 70s," p.403.

26. Mitchell and Swieszkowski, "Publication Requirements and Tenure Approval Rates," p.253.

27. Susan L. Miller and others, "To Be or Not to Be: An Academic Library Research Committee," Journal of Academic Librarianship 2:20 (Mar. 1976).

28. Darrell L. Jenkins, M. Kathy Cook, and Mary Anne Fox, "Research Development of Academic Librarians: One University's Approach," Journal of Academic Librarianship 7:83-86 (May 1981).

29. Page Ackerman, "Governance and Academic Libraries," Library Research 2:3-28 (1980-81).

30. Adeline Tallau and Benjamin R. Beede, "Faculty Status and Library Governance," Library Journal 99:1521 (June 1, 1974).

31. Robert G. Sewell, "Faculty Status and Librarians: The Rationale and the Case of Illinois," College and Research Libraries 44:214 (May 1983).

32. Tallau and Beede, "Faculty Status and Library Governance," p.1521-23.

33. Dorothy H. Cieslicki, "A New Status Model for Academic Librarians," Journal of Academic Librarianship 8:76-81 (May 1982).

34. Michael McDavid, "Beyond Faculty Status: Creating a Library Constitution," Southeastern Librarian 29:218-20 (Winter 1979).

35. Richard W. Meyer, "Library Professionalism and the Democratic Way, Journal of Academic Librarianship 6:279 (Nov. 1980).

36. Ibid., p.281.

37. Louise Sherby, "Academic Librarian: Librarian or Faculty Member?" in Essays from the New England Academic Librarians' Writing Seminar, ed. Norman Stevens (Metuchen, N.J.: Scarecrow, 1980), p.52-54.

38. Pauline Wilson, "Librarians as Teachers: The Study of an Organization Fiction," Library Quarterly 49:149 (Apr. 1979).

39. David Peele, "Librarians as Teachers: Some Reality, Mostly Myth," Journal of Academic Librarianship 10:269 (Nov. 1984).

40. John Budd, "Librarians Are Teachers," Library Journal 107:1945 (Oct. 15, 1982).

41. Ibid., p.1946.

42. Mary Biggs, "Sources of Tension and Conflict between Librarians and Faculty," Journal of Higher Education 52:194-98 (Mar.-Apr. 1981).

43. Mary M. Huston and Frank Motley, "Faculty Membership for Librarians: The Evergreen State College Model," in Options for the Eighties: Proceedings of the Second National Conference of the Association of College and Research Libraries, eds. Michael D. Kathman and Virgil F. Massman (Greenwich, Conn.: JAI Press, 1982), p.413-19.

44. M. Kathy Cook, "Rank, Status, and Contribution of Academic Librarians as Perceived by the Teaching Faculty at Southern Illinois University, Carbondale," College and Research Libraries 42:214-23 (May 1981); English, "Administrators' Views of Library Personnel Status," p.189-95.

45. Biggs, "Sources of Tension and Conflict between Librarians and Faculty," p.194-95; Wilson, "Librarians as Teachers," p.153-54.

46. Wilson, "Librarians as Teachers," p.154. 
47. Margaret Beckman, "Implications for Academic Libraries," in Collective Bargaining in Libraries, ed. Frederick A. Schlipf (Urbana, Ill.: Univ. of Illinois Graduate Sch. of Library Science, 1975), p.122.

48. Millicent D. Abell, ed., Collective Bargaining in Higher Education: Its Implications for Governance and Faculty Status for Librarians (Chicago: American Library Assn., 1976); Beckman, "Implications for Academic Libraries," p.122-45; Stella Bentley, "Collective Bargaining and Faculty Status," Journal of Academic Librarianship 4:75-81 (May 1978); Mary Anne Burns and Jeanette Carter, "Collective Bargaining and Faculty Status for Librarians: West Chester State College," College and Research Libraries 36:115-20 (Mar. 1975); Paul H. Gaboriault, "Collective Bargaining in Massachusetts Colleges: What Library Directors Think," Journal of Academic Librarianship 3:4-9 (Mar. 1977); Lynn Marko, "SCMAI Case Report: Librarians in Faculty Unions-A Case Study," American Libraries 10:195-97 (Apr. 1979); Julie Schroeder, "The Appropriate Bargaining Unit for the Academic Librarian," IPLO Quarterly (Institute of Professional Librarians of Ontario) 17:155-70 (Jan. 1976); Lothar Spang, "Collective Bargaining and University Librarians: Wayne State University," College and Research Libraries 36:106-14 (Mar. 1975); John Weatherford, "Librarians in Faculty Unions," Library Journal 99:2443-46 (Oct. 1, 1974); John Weatherford, "Participatory Something or Other through Bargaining," Library Journal 100:823-25 (May 1, 1975); John Weatherford, Collective Bargaining and the Academic Librarian (Metuchen, N.J.: Scarecrow, 1976); Belle Zeller, "The Academic Librarian: Collective Bargaining and Faculty Status," Catholic Library World 47:60-63 (Sept. 1975).

49. "Picket Lines and Paradises," Library Journal 110:20 + (Dec. 1985).

50. Weatherford, "Librarians in Faculty Unions," p.2444.

51. Zeller, "The Academic Librarian: Collective Bargaining and Faculty Status," p.63.

52. David G. E. Sparks, "Academic Librarianship: Professional Strivings and Political Realities, " College and Research Libraries 41:417 (Sept. 1980).

53. David H. Kreh, "Faculty Status and Collective Bargaining: SUNY Libraries 1965-1982," The Bookmark 40:195-99 (Summer 1982).

54. Bentley, "Collective Bargaining and Faculty Status," p.76.

55. Weatherford, "Participatory Something or Other through Bargaining," p. 825

56. Sparks, "Academic Librarianship: Professional Strivings and Political Realities," p.419. 